\section{Comparative Analysis of the Composition of the Volatile Oils of Two Forms of Achillea crithmifolia W. et. K. - Diploid and Tetra- ploid}

Adam Kowalczyk ${ }^{\mathrm{a} *}$, Janina Dąbrowska ${ }^{\mathrm{b}}$, Marek Mardarowicz ${ }^{\mathrm{c}}$, Izabela Fecka ${ }^{\mathrm{a}}$, and Wojciech Cisowski ${ }^{\mathrm{a}}$

a Dept. of Pharmacognosy, Wrocław Medicinal University, Nankiera 1, 50-140 Wrocław, Poland.

Fax: ++48-71-7840218. E-mail: akow2@poczta.onet.pl

b Institute of Botany, Wrocław University, Maxa Borna 9, 50-206 Wrocław, Poland

c Dept.of Chemical Physics and Physico-Chemical Methods of Separation, Maria Curie-Skłodowska University, M. Curie-Skłodowska sq. 3, 20-031 Lublin, Poland

* Author for correspondence and reprint requests

Z. Naturforsch. 58c, 146-147 (2003); received June 11/August 29, 2002

The genus Achillea $\mathrm{L}$. includes more than 100 species and is a polyploid complex of di-, tetra-, hexa- and octaploids, individuals.

Key words: Achillea crithmifolia, Voltile Oil, Diploid Tetraploid

Achillea crithmifolia $\mathrm{W}$. et $\mathrm{K}$. is one of the ten currently known Achillea taxa and exists in two forms: diploid $(2 \mathrm{n}=18$, noted for example in Greece) and tetraploid $(2 \mathrm{n}=36)$. Between these forms there are some differences, which were observed by Dąbrowska (Dąbrowska, 1971, 1972, 2001).

Diploid and tetraploid forms ( or the polyploids) may differ chemically so it is an interesting problem to what extent the compositions of the volatile oils of these two forms of A. crithmifolia.

\section{Material and Methods}

\section{Material}

The analysed plants were growing in a collection in Wrocław, but were originally collected in nature. The diploid form was from Greece and tetraploid from Poland (Lower Silesia, Gubin).

Herbs were collected during flowering in the summer 2001. Plant material was identified and determined by J. Dąbrowska.

\section{Isolation of oil fractions}

$20.0 \mathrm{~g}$ of each material, previously air-dried, was distilled with water vapour in Deryng apparatus, according to the method of obtaining and measuring volatile oil described in the Polish Pharmacopeia FPV for Achillea millefolium (Polish Pharmacopeia 1999). The plant material was placed in the glass flask with the $200 \mathrm{ml}$ water. The flask was connected with Deryng apparatus and heated $3 \mathrm{~h}$ on the water bath. After that the oil fraction was analysed by GC-MS.

\section{Chromatographic analysis}

Chromatographic analysis was carried out using gas chromatograph HP 5890, series II, coupled with mass spectrophotometer HP 5971A. Analysis parameters were: capillary column HP-1.25 m, ionisation energy $70 \mathrm{eV}$, carrier gas helium, flow speed: $0.5 \mathrm{ml} / \mathrm{min}$, temperature increase from 80 to $300{ }^{\circ} \mathrm{C}$ at a rate of $8{ }^{\circ} \mathrm{C} / \mathrm{min}$. The resulting spectra were compared with the data from the data library IVB575KL (Finnigan Mat, San José, USA).

All the experiments were repeated three times.

\section{Results and Discussion}

The mean content of volatile oil in the herb A.crithmifolia diploid is $2 \% \pm 0.05(\mathrm{v} / \mathrm{w})$ and in the tetraploid $-2.1 \% \pm 0.052(\mathrm{v} / \mathrm{w})$. Most of the oil was distilled during the first $30 \mathrm{~min}$ of heating. Chromatographic analysis GC-MS revealed the main differences and similarities between the diploid and the tetraploid forms of A.crithmifolia (Fig. 1).

In the volatile oil of the diploid 1,8-cineole $(17.9 \% \pm 0.03)$ is the main component and in the tetraploid - camphor $(21.4 \% \pm 0.02)$.

The diploid oil in comparison with the tetraploid has more $\beta$-thujone $(18.3 \% \pm 0.01)$, trans-chrysanthenyl acetate $(14.9 \% \pm 0.02)$, germacrane $\mathrm{D}$ $(2.5 \% \pm 0.04)$ and less camphor $(4,1 \% \pm 0.01)$ and borneol $(1.7 \% \pm 0.03)$

The tetraploid form of the oil contains more borneol $(12.1 \% \pm 0.02)$ and less 1,8 -cineole $(2.5 \%$ $\pm 0.03)$, $\beta$-thujone $(4.8 \% \pm 0.03)$, trans-chrysan- 

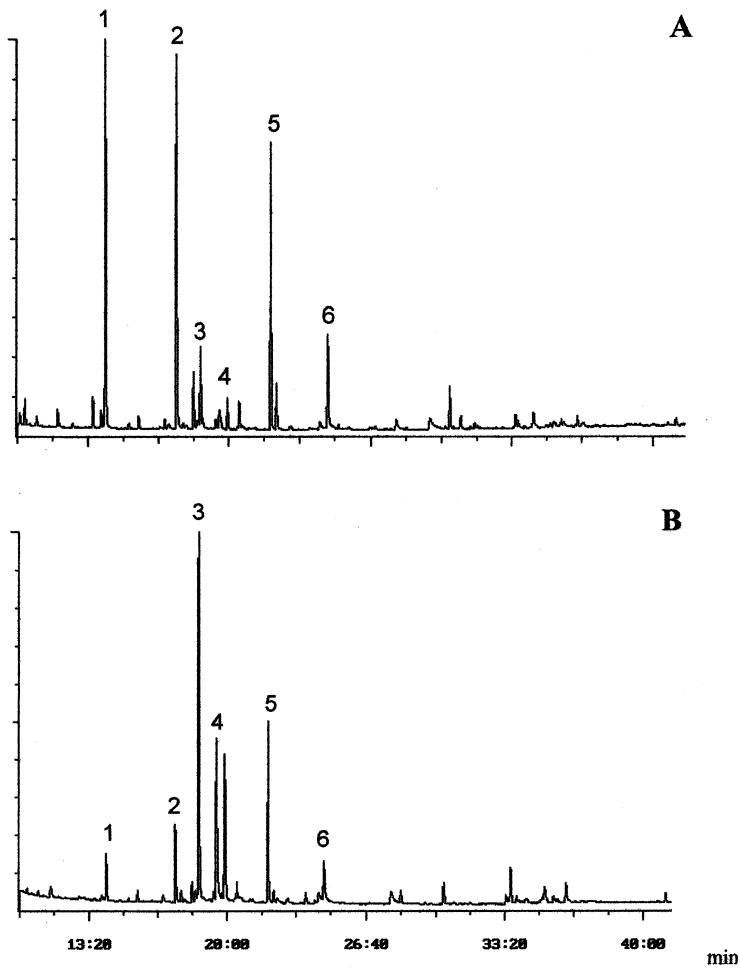

Fig. 1. GC chromatograms of volatile oil of A.crithmifolia - A - diploid; B - tetraploid.

$\mathbf{1}$ - 1,8-cineole $\mathbf{2}$ - $\beta$-thujone $\mathbf{3}$ - camphor $\mathbf{4}$ - borneol 5 - trans-chrysanthenyl acetate $\mathbf{6}$ - germacrene D.

Dąbrowska J. (1971), Korelacja między liczbą chromosomów w komórkach szparkowych a poziomem poliploidalno[ci czternastu taksonów Achillea L. Herba Polon. 17, 200-208.

Dạbrowska J. (1972), Achillea crithmofolia W. et K. - A synanthropic species new to the flora of Poland Fragm. Flor. et Geobot. 18, 147-151. thenyl acetate $(10.2 \pm 0.02)$, germacrene $\mathrm{D}(1.5 \%$ $\pm 0.01)$ than the diploid form.

The differences in the chemical compositions of the volatile oils in both forms, diploid and tetraploid, are valuable data which can emphasize that it is very important to know the numbers of chromosomes in the analysed plant material, because the presence of natural compounds could be different in taxa with similar morphology and anatomy.

Chromatographic analysis together with the chromosome data may give more information about plants and can help to establish relationships between taxa.
Dąbrowska J. (2001) Achillea crithmifolia in di- and tetraploid forms Proceedings of the $2^{\text {nd }}$ Balkan Botanical Congress, Istanbul, Turkey, 2000, 447-450.

Polish Pharmacopeia, Polskie Towarzystwo Farmaceutyczne, Warszawa (1999), p. 464. 